2016

\title{
Markets, Globalization, Development: Charting the Intersections of Three Multipolar Concepts
}

\author{
Nikhilesh Dholakia \\ University of Rhode Island \\ Deniz Atik \\ izmir University of Economics
}

Follow this and additional works at: https://digitalcommons.uri.edu/mgdr

Part of the Anthropology Commons, Economics Commons, Marketing Commons, Other Business Commons, and the Sociology Commons

\section{Recommended Citation}

Dholakia, Nikhilesh and Atik, Deniz (2016) "Markets, Globalization, Development: Charting the Intersections of Three Multipolar Concepts," Markets, Globalization \& Development Review: Vol. 1: No. 1, Article 1.

DOI: 10.23860/MGDR-2016-01-01-01

Available at: https://digitalcommons.uri.edu/mgdr/vol1/iss1/1

This Article is brought to you for free and open access by DigitalCommons@URI. It has been accepted for inclusion in Markets, Globalization \& Development Review by an authorized editor of DigitalCommons@URI. For more information, please contact digitalcommons-group@uri.edu. 
Markets, Globalization, Development: Charting the Intersections of Three Multipolar Concepts

\section{Markets, Globalization \& Development Review}
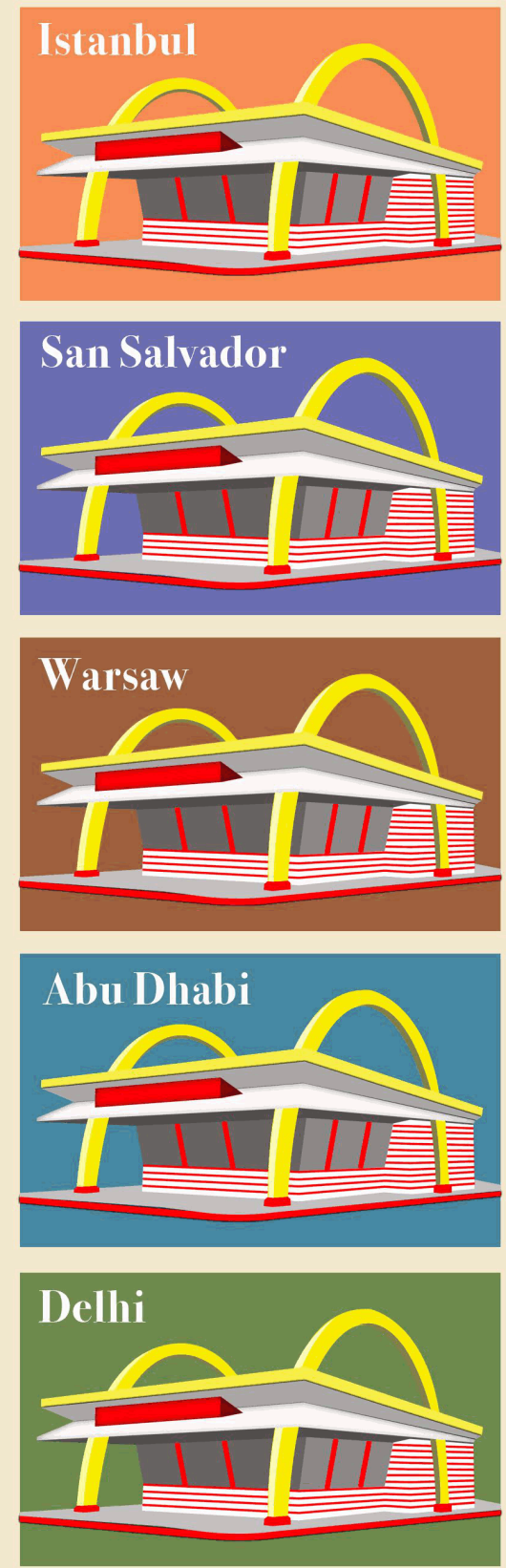
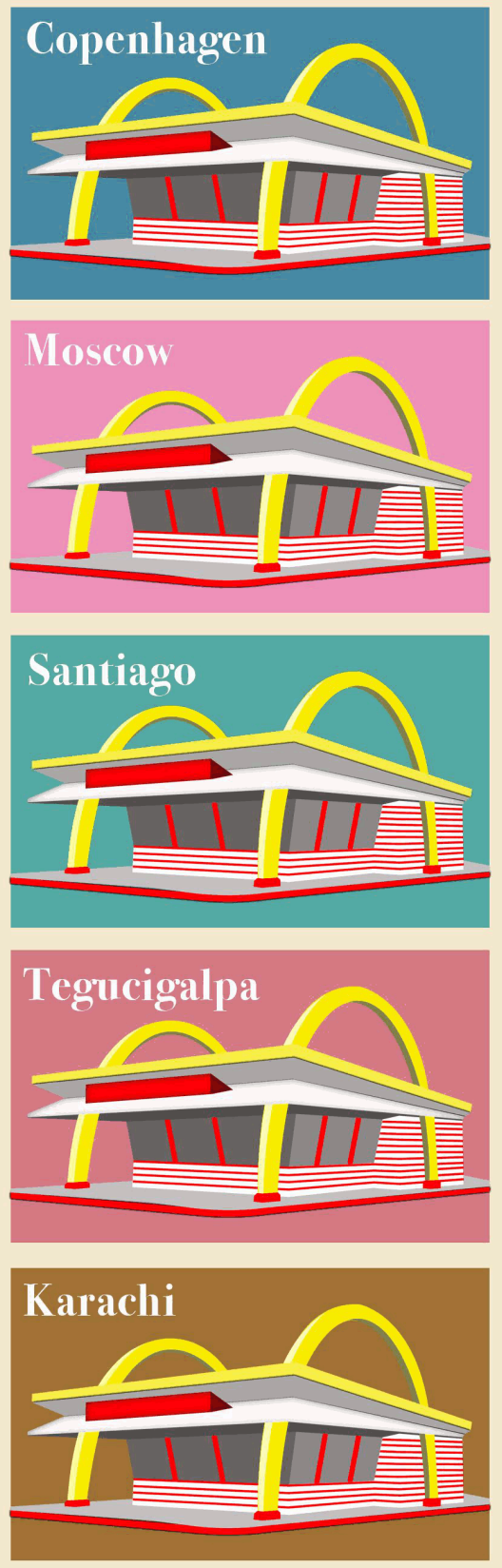
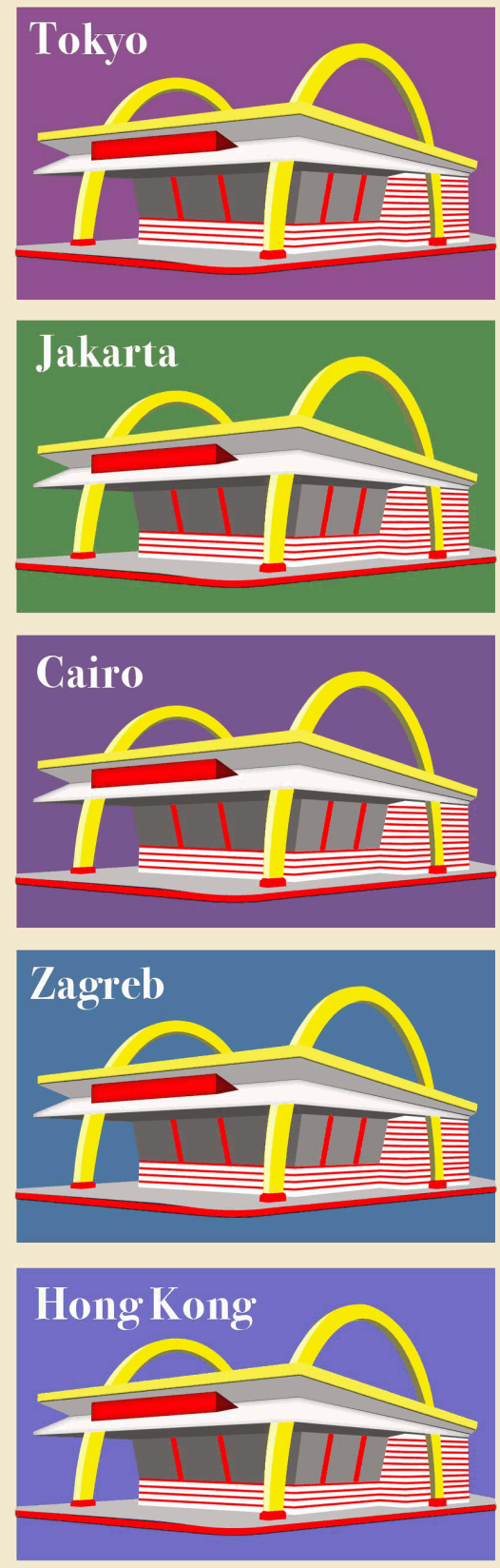

This article is available in Markets, Globalization \& Development Review: https://digitalcommons.uri.edu/mgdr/vol1/ 


\section{Markets, Globalization, Development: Charting the Intersections of Three Multipolar Concepts}

\section{Introduction}

It should be immediately evident to those downloading and reading this opening article, penned by the founding editors, introducing the new journal Markets, Globalization \& Development Review, MGDR for short, that three momentous, weighty and contested concepts are part of the title of the journal. In this introductory essay, we want to lay out an editorial view of how we see the three main concepts - markets, globalization and development - playing out in the wide world out there, as well as, to the extent possible, in the pages of this journal.

Our views that follow do not represent dogmas or rigid positions; rather, they are indicative of the evolutionary and intersecting views of these concepts that we have developed, from our experiences and readings. We realize fully that our own views of these three concepts would continue to evolve further, especially from the innovative and insightful contributions that we hope to see in the pages of this journal, and also from our own personal ongoing intellectual and other life experiences. What we want to implore with our contributing authors is to keep a spirit of openness in their writings; a receptivity to alternate, contested, controversial and evolving views. This is because - while open and flexible on other matters - we are rigidly sure of one thing: we have not reached the end of history (Fukuyama 2006). We believe that better worlds lie ahead, even though some of the pathways may be murky and even retrograde.

Markets, globalization and development - each represent contested terrains for major intellectual ideas of our times. Each concept is multipolar, often with views that are of a daggers-drawn inimical nature. Even when there is reasonable convergence, there are contested variations - eddies and cross-currents - within a stream that seemingly is rushing in a unidirectional fashion. This is the reason why "development" is always an ongoing project, even for the richest places on earth. Development is a work in progress, and not a realized end state. We would discourage, therefore, the use (or suggest minimal use) of labels such as developed, less developed, and underdeveloped - unless the exact context requires such use. We do realize of course that distinctions have to be made in discussions as well as in policies; and therefore we would "live with" labels such as advanced and emerging, rich and midincome and poor, industrial and agrarian (and postindustrial), 
technologically advanced, culturally opulent, ancient and modern (and postmodern), colonial and colonized and postcolonial, Third World and First World.

With this prefatory note, we now present - in a very condensed way - our mid-2016 assessment of the three core concepts of markets, globalization and development.

\section{Markets}

As places of exchange, markets have existed since the ancient agoras (Polanyi 1957). A fundamental shift in the view and role of markets occurred in Europe in the decades and centuries following Enlightenment. From a place of periodic exchange in ancient times, in modern times, the market became the pervasive economic institution for exchange value creation, the fulcrum around which the entire capitalist system revolves. With the political intensification and acceleration of forces that were blindly pro-market "the economic domain took center stage in modern cultures and modern liberalist ideology transformed into neoliberalist ideology, making the market the sole arbiter of all modernist ideals and enshrining economic value as the dominant organizing principle of all key institutions" (FIrat and Dholakia 2017). This searing ascendance of 'the market' has led to a confounding and conflating of markets and capitalism, sweeping under the rug the ancient patterns of markets as periodic exchange systems as well as myriad and smaller contemporary forms of markets that are not quite fully capitalist. In this journal, while works on capitalist markets are welcome, we want to break away from the conflation and false equivalence of markets and capitalism. We want to encourage studies that explore markets in their variegated, including non-capitalist and quasi-capitalist, forms; and probe the ways in which markets cooperate as well as collide with non-market forms of making goods and services available to people. To anyone dealing with modern public policy issues, the study of such conflictual-cooperative processes is quite central as witnessed, for example, in the pitched political contests about healthcare surrounding the Affordable Care Act in the United States. The key policy debate issue, in the U.S. healthcare situation and in similar contexts, is whether (or in what combination) market-based or nonmarket-based methods should be employed to deliver essential services such as healthcare.

We believe it is time for applied disciplines, such as business and law, to not only engage seriously in studying market and non-market dynamics but also to come up with novel ways to use markets and their 
alternatives to better human lives; without slavish, one-track adherence to the idea of relentless and totalizing 'marketization'.

\section{Globalization}

Compared to markets, globalization is a new idea, an idea born in late modernity (Featherstone 1990). While it is possible to do a rearview conceptualization and characterize ancient forms of cross-global connections, such as the Silk Road journeys, as a form of globalization (Foltz 2010; Garten 2016), the real seeds of globalization are traceable to the voyages of European merchant explorers and, later, to the European imperialist expeditions and expansions (Abernethy 2000). Even these phenomena - including Pax Britannica, a globe-spanning empire on which the sun never set - managed to create wide-ranging global political, economic and cultural connections; but not quite globalization as we know it today. It is only in the contemporary largely decolonized world of a very diverse mix of rich and poor, culturally variegated nations - linked by a thick web of capital and trade and cultural flows, along with a thinner web of migratory flows; and lately by electronic communications - that globalization has become entrenched, even inevitable (Appadurai 1990). Following the 2016 "Leave EU" vote in the so-called Brexit referendum in Britain, Reinhart (2016) offered this assessment of the contemporary history of globalization, pointing to the wave-like up-down character of modern globalization:

The latter part of the nineteenth century, despite its technological limitations, was an era of rising global trade. Major waves of immigration radically diversified the demographic makeup of the US and other parts of North and South America. London was host to a rapidly growing global financial industry, as it had been since the time Britain emerged victorious from the Napoleonic Wars... World War I ended this earlier wave of globalization... After WWII, global integration finally began anew, first in trade and then, since the 1980s, in finance. During this time, London's financial center awoke from its long slumber and helped the UK become one of the pillars of a new, deeply integrated international political economy. Prior to the 2008-2009 global financial crisis, most indicators of global trade and finance had reached new peaks, and European unification contributed significantly this... The global financial crisis dealt a significant blow to globalization, especially in terms of trade and finance. Now Brexit has dealt another blow, adding labor mobility to the list. 
While we do not wish to oversimplify the intertwined strands and processes of globalization, for the MGDR readers and writers, we do want to suggest three basic and straightforward lenses to view globalization: globalization of capital, globalization of culture, and globalization of people. Of these, globalization of capital has been the driving force, and therefore also the main drawback of globalization. If globalization implies oneness and unity of our planet, then the capital-driven globalization has been lopsided, favoring the centers of global finance (Dholakia 2011) and shortchanging practically every other location or group. Anti-globalization movements of all types are essentially expressing resistance to the hegemonic, capital-controlled forms of globalization. It is important to note that even avid anti-globalization activists rely strongly on, indeed encourage and reinforce, the globalizing tools that entail cultural exchange, worldwide communications, and boundary-spanning social media connections.

Globalization of culture, while facilitated strongly by the big media conglomerates that are closely allied to and controlled by global centers of finance, nonetheless offers opportunities for masses of ordinary people to exchange information and ideas, especially with the pervasive availability of connected devices and social media. Globalization of people - travel, tourism, relationships, migration and more - has the potential to promote harmony and understanding and peace; but is often perversely diverted and implicated in political processes that promote disharmony, fractiousness, even hate.

The challenge for all peoples in the world - including for the readers of and contributors to MGDR - is to seek a rebalancing of the globalization boat. At present, our 'globalization boat' is tilting and listing and lurching precariously in treacherous waters because of the immense weight of capital-driven globalization. To paraphrase a quote, attributed, most likely spuriously, to Lenin - "The Capitalists will sell us the rope with which we will hang them" - the capitalists are prone to overload the boat of globalization precariously with their narrow financial interests, even if it leads to the sinking of the boat. The rebalancing calls for much greater and stronger roles for culture-based globalization and people-oriented globalization in the political, economic and social affairs of the contemporary world.

The founding and ascendance of several international institutions to facilitate international trade, economic growth and global fiscal discipline (e.g., WTO, IMF) have led to the globalization goals and processes especially the globalization-of-capital - becoming deeply enmeshed and embedded in public and private governance, and in the everyday life of 
people. By contrast, the institutional meshes for culture-oriented and people-oriented globalization (e.g., World Social Forum 2016) are thin, often threadbare, and managed by resource-constrained non-government organizations (NGOs) rather than by resource-rich governments and corporations. One of our goals at MGDR would be to explore ways to strengthen and reinforce these 'rebalancing' globalization meshes.

\section{Development}

The idea of development has gone through many vicissitudes and contestations, shaped by ideology, political upheavals, economic conditions, policy 'miracles' (Page 1994) and malaise (Lincoln 2004), and sociocultural forces. The fairly simplistic stage-by-stage laddered views of development (Rostow 1960/1990; Germani 1969) have been challenged, subverted, diverted, or inverted by a variety of "development models" ranging from 'revolutions' (Conway and Barbier 2013) to "tiger" economies (Lall 2000) to BRIC-style emerging economies (Holtbrügge and Kreppel 2012) to statist-capitalist formations (Boisot and Child 1996) to theocracyled patterns (Gheissari 2009), and even fallen-from-grace examples (Della Paolera and Taylor 2003). Indeed, serious development scholars have long recognized that straitjacketing of complex processes such as modernization and development into simple and rather deterministic frames does not usually work (e.g., Bernstein 1971).

At MGDR, we want to view development in the very basic frame of amelioration, enhancement and progress. These processes do not come to a halt at any particular level of economic or technological achievement. It is always possible to do better than the current state, and therefore development is an ongoing topic relevant for all parts of the world.

At some recent historical junctures - in particular, in the aftermaths of the Bolshevik revolution in Russia and the Maoist revolution in China development, its concepts and strategies, have been hotly contested ideological terrains. The entire Cold War can be seen as a contest between alternative development pathways. Cuba, almost singly, struggles on as an exemplar of the alternative path (Eckstein 2004); but the disintegration of the Soviet Union has convinced some that the only viable path for development is the capitalist - nay, the neoliberal and neoconservative capitalist - path (Fukuyama 2006; Huntington 2012). The continued mega-challenges of poverty and deprivation (see Achrol and Kotler 2016, this issue of MGDR), however, make it amply clear that the end of the Cold War, and especially the searing rise of the neoliberal options (Harvey 2007), do not represent silver-bullet solutions to the challenges of economic, social, human development. Indeed, as the 
pages of this journal will show - they already do in this inaugural issue there are multiple ways to analyze and deal with developmental challenges.

\section{Intersections}

Markets, globalization and development - each of these have some degrees of inevitabilities and some element of inexorability. The battles of ideas and ideologies are often around which concepts, and which of their versions of the concepts, have the most compellingly inexorable character.

For the neoliberal, neoconservative mindset, the inevitability and inexorability is the triumph of a certain kind of market and a certain kind of globalization (Foucault 2008): a market in which the competitively craftier actors - typically the ones strongly supported by (or wildly bet upon by) financial capital - win, first in their home bases and then worldwide. Globalization, thus, is the global spread of such market actors, their activities, their practices and their institutions - brands as well as their Finanzkapital controllers and handlers.

Development - in this way of thinking - is a race in which nations and regions are urged to "reform" in ways that (and until the days when) such financially-deft, quasi-monopolistic 'competitive' winning strategies and practices become the norm of the nation or the region. Development comes to a full stop when this state has been achieved; and then the job of public and private policies is to maintain this "advanced, developed, blissful" neoliberal state of affairs.

It should be self-evident that, for MGDR, this is a caricatured view of markets, globalization and development - a view that is fairly strongly touted, but does not represent the situation of over $90 \%$ of the world's people (but does represent the way about a third of the world economic output is produced and managed).

In the pages of MGDR, we do not want this neolib-neocon tail to wag the global dog: neither the under-five-percent demographic tail of those who believe in and tout such policies nor the stronger, but still a minority, tail of the part of the world economy that is orchestrated from the elite but extremely narrow slivers of financially mega-powerful urban geographies. We of course remain open to even these tail-(tale)-spinning views; but in the spirit of discussion and debate, not as received wisdom on how to run organizations and nations.

The question we want to open up for debate in the pages of MGDR is not about being for or against the market, but what do we understand from the term -an economic arena of competing prices, costs, and 
profits, or a social space that is governed by competing "values" of various kinds (social, economic, cultural, ecological)? In other words, can the notion of market be revised as an extension of the social, as an enriching cooperative and collaborative social practice, rather than a competitive environment governed only by the laws of increasingly monopolistic economic profit?

\section{Discussion and Concluding Comments}

Market has become a pivotal term around which almost every social, political and economic relation is organized. Under neoliberal economic policies and postfordist production relations, market becomes synonymous with capitalist development that promises potential wealth and wellbeing. Yet, that promise remains highly questionable. Apart from the chronic shortcomings of what that potential 'capitalist development' may turn out to be, the market often excludes and alienates growing masses (see Achrol and Kotler 2016, this MGDR issue). The market also spawns frequent global crises, especially asset-bubble inflate-and-burst phenomena of various kinds (Dholakia and Turcan 2013, 2014). In the pages of MGDR, we seek to move beyond the mundane political debates that situate us as "anti-" or "pro-" market, beyond the buzzwords and empty signifiers, and to generate debates around the weighty concepts of markets, globalization and development in their contemporary variety as well as in historical variations and depth.

We would eschew the inclination to do the typical overview of articles that typical appears in the inaugural issue of a journal. In this issue of MGDR, as you will see, the articles that follow are varied, informative, often provocative, and in general balanced in their treatment of conflicting views and theories.

What we want to leave you, the reader and potential contributor, is with the shared challenge of our time: how to make the world better, cleaner, safer, peaceful, provident, tolerant, harmonious and fairer; in other words, how to embark on paths and projects of development that have way-stations that are better than the starting points. We have already indicated one bias that we have at MGDR: development is a journey, not a race with an end point. We urge you all to enjoin this journey. 


\section{References}

Abernethy, David B. (2000), The Dynamics of Global Dominance: European Overseas Empires, 1415-1980. New Haven CT: Yale University Press.

Achrol, Ravi S. and Philip Kotler (2016), "Marketing's Lost Frontier: The Poor", Markets, Globalization \& Development Review, 1 (1).

Appadurai, Arjun (1990), "Disjuncture and Difference in the Global Cultural Economy", Public Culture, 2 (2), 1-24.

Bernstein, Henry (1971), "Modernization theory and the sociological study of development", Journal of Development Studies, 7 (2), 141-160.

Boisot, Max and John Child (1996), "From fiefs to clans and network capitalism: Explaining China's emerging economic order", Administrative Science Quarterly , 41 (4), 600-628.

Conway, Gordon R. and Edward B. Barbier (2013), After the Green Revolution: Sustainable Agriculture for Development, London: Earthscan Publishing.

Della Paolera, Gerardo and Alan M. Taylor (2003), A New Economic History of Argentina, Cambridge UK: Cambridge University Press.

Dholakia, Nikhilesh (2011), "Finanzkapital in the twenty-first century", critical perspectives on international business, 7 (1), 90108.

Dholakia, Nikhilesh and Romeo V. Turcan (2013), "Bubbles: Towards a typology", Foresight, 15 (2), 79-88.

Dholakia, Nikhilesh and Romeo V. Turcan (2014), Toward a Metatheory of Economic Bubbles: Socio-political and Cultural Perspectives, New York: Palgrave Macmillan.

Eckstein, Susan Eva (2004), Back from the Future: Cuba under Castro. New York: Routledge.

Featherstone, Mike (1990), Global culture: Nationalism, Globalization and Modernity. London: Sage.

Fırat, A. Fuat and Nikhilesh Dholakia (2006), "Theoretical and philosophical implications of postmodern debates: some challenges to modern marketing," Marketing Theory, 6, 123-162. 
Fırat, A. Fuat and Nikhilesh Dholakia (2017), "Market and Community: May the Twain Meet?", Consumption, Markets \& Culture (forthcoming).

Foltz, Richard (2010), Religions of the Silk Road: Premodern Patterns of Globalization, New York: Palgrave Macmillan.

Foucault, Michel (2008), The Birth of Biopolitics (Lectures at Collège de France 1978-79), London, New York: Palgrave Macmillan

Fukuyama, Francis (2006), The end of history and the last man, New York: Simon and Schuster.

Garten, Jeffrey (2016), From Silk to Silicon: The Story of Globalization Through Ten Extraordinary Lives, Amberley Publishing.

Germani, Gino (1969), "Stages of Modernization”, International Journal, 4 (3), 463-485.

Gheissari, Ali, ed. (2009), Contemporary Iran: Economy, Society, Politics. Oxford UK: Oxford University Press.

Giddens, Anthony (2009), Sociology, London: Polity Press.

Harvey, David (2007), A Brief History of Neoliberalism. New York: Oxford University Press.

Holtbrügge, Dirk and Heidi Kreppel (2012), "Determinants of outward foreign direct investment from BRIC countries: an explorative study", International Journal of Emerging Markets, 7 (1), 4-30.

Huntington, Samuel P. (2012), The Third Wave: Democratization in the Late 20th Century, Norman OK: University of Oklahoma Press.

Lall, Sanjaya (2000), "Technological change and industrialization in the Asian newly industrializing economies: achievements and challenges", in L. Kim and R.R. Nelson, eds., Technology, learning, \& innovation: Experiences of newly industrializing economies, Cambridge UK: Cambridge University Press, 13-68.

Lincoln, Edward J. (2004), Arthritic Japan: the slow pace of economic reform, Washington DC: Brookings Institution Press.

Page, John M. (1994), "The East Asian miracle: an introduction", World Development, 22 (4), 615-625.

Polanyi, Karl (1957), The Great Transformation: The Political and Economic Origins of Our Time. Boston, MA: Beacon Press. 
Reinhart, Carmen (2016), "Brexit's Blow to Globalization", Project Syndicate website, June 29, (accessed July 3, 2016) [available at: https://goo.gl/xcCZUg].

Rostow, Walt Whitman (1960/1990), The stages of economic growth: $A$ non-communist manifesto, $1^{\text {st }}$ edition (1960), $3^{\text {rd }}$ edition (1990), Cambridge UK: Cambridge University Press.

Sen, Amartya K. (1970), Collective Choice and Social Welfare, San Francisco: Holden-Day.

World Social Forum (2016), "Another World is Needed. Together, It is Possible.", 9-14 August, Montreal, (accessed July 29, 2016) [available at https://fsm2016.org/en/] 